\title{
Increasing relative abundance of Porites astreoides on Caribbean reefs mediated by an overall decline in coral cover
}

\author{
Daniel H. Green, Peter J. Edmunds*, Robert C. Carpenter \\ Department of Biology, California State University, 18111 Nordhoff Street, Northridge, California 91330-8303, USA
}

ABSTRACT: On most coral reefs, the percentage cover of scleractinian corals has declined greatly over the last $30 \mathrm{yr}$; some species that are more resistant to mortality have been less affected than others. Porites astreoides is one species that has become a more prominent component of coral reef communities throughout the Caribbean. Analyses of coral reefs in shallow water (5 to $6 \mathrm{~m}$ depth) at 6 locations spanning a $4100 \mathrm{~km}$ arc of the Caribbean were used to evaluate the contribution of $P$. astreoides to contemporary reefs. Photoquadrats recorded in 2003/2004 were used to estimate the percentage cover and colony density of $P$. astreoides, and colony size-frequency structure was analyzed to gain insight into demographic processes. At all locations, reefs were characterized by $<15 \%$ coral cover, but 16 to $72 \%$ of this cover was $P$. astreoides, at mean densities of 1.76 colonies per $0.25 \mathrm{~m}^{2}$. Most of these colonies $(62 \%)$ were $\leq 50 \mathrm{~cm}^{2}$ in size, demonstrating that the populations were young and influenced strongly by recruitment. Comparison to historical data collected between 1974 and 1992 suggests that the relative percentage cover of $P$. astreoides in shallow water reef habitats has increased at a rate of $1.5 \% \mathrm{yr}^{-1}$, from $<20 \%$ in the 1970 s to $50 \%$ in $2003 / 2004$. These findings indicate that community structure of Caribbean coral reefs is changing on a decadal time scale to become dominated by 'weedy' corals that form rapidly growing, small colonies that are short lived and quickly replaced.

KEY WORDS: Porites astreoides · Population dynamics · Coral reef $\cdot$ Decadal scale

Resale or republication not permitted without written consent of the publisher

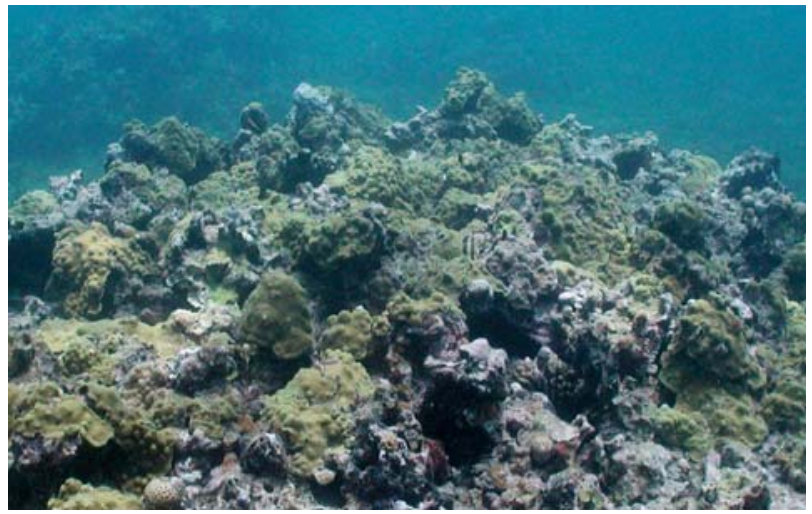

Shallow coral reef (6 m depth) in Grenada, West Indies, where Porites astreoides is the dominant coral.

Photo: P. J. Edmunds

\section{INTRODUCTION}

On a global scale, many coral reefs have lost $>50 \%$ of their coral over the last 3 decades (Gardner et al. 2003, Bellwood et al. 2004); losses caused by anthropogenic effects probably began as early as the 17 th century (Jackson 1997, Pandolfi et al. 2005). There is substantial literature addressing the causes of these losses (Hoegh-Guldberg 1999, Knowlton 2001, Bellwood et al. 2004), but a long-term prognosis for coral reefs remains difficult (Knowlton 2001, Pandolfi et al. 2005), and the study of the factors causing declining coral cover continues to be an important research objective. 
Research has focused on losses of coral cover (Jackson 1997, Gardner et al. 2003), the death of ecologically important coral species (Aronson \& Precht 2001), and the study of macroalgae that typically replace these corals (Knowlton 2001), but subtle patterns in coral community dynamics tend to be overlooked. For instance, in contrast to the overwhelming quantity of literature addressing declining coral cover, less attention has been paid to the fact that small areas of reefs can deviate from this trend (Edmunds \& Bruno 1996), and therefore it is noteworthy when patches of healthy reef are discovered (Idjadi et al. 2006). Despite a Caribbean-wide decline in coral reefs (Gardner et al. 2003), there have also been increases in coral recruitment and population recovery in the urchin Diadema antillarum (Carpenter \& Edmunds 2006, Mumby et al. 2007). One important aspect of the changing face of coral communities is the potential for regional increases in abundance of corals that survive large-scale disturbances such as hurricanes or mass bleaching events. This is of central importance to understanding how coral reefs will change, if they do not disappear entirely (Hughes et al. 2003), and determining future ecological features of a coral species.

In the Caribbean, Porites astreoides is one of a small suite of species with the potential for surviving disturbances, because it has a weedy life-history strategy (Knowlton 2001) marked by short longevity (Soong 1991), relatively high fecundity (Chornesky \& Peters 1987, McGuire 1998), and the production of brooded larvae (McGuire 1998) that typically settle at high densities (Bak \& Engel 1979). Moreover, P. astreoides thrives in a variety of shallow water habitats, including some that are suboptimal for coral growth (Tomascik \& Sanders 1987); analyses of fossilized Pleistocene reefs demonstrate that this species has been a component of Caribbean reefs for millennia (Pandolfi \& Jackson 2006). The fossil record also contains evidence that $P$. astreoides probably was less affected than other scleractinians during the early Miocene, a period of region-wide adverse conditions when cold and turbid conditions favored brooding, eurytopic coral genera (e.g. P. astreoides) over broadcasting, stenotopic genera (Edinger \& Risk 1995, Aronson \& Precht 2001). This suggests that $P$. astreoides may have fared better in comparison to other corals during the most recent period of adverse conditions affecting Caribbean reefs.

The objectives of this study were to (1) describe contemporary coral community structure at multiple locations spanning the width of the Caribbean, in order to evaluate the contribution of Porites astreoides to these communities; (2) quantify the colony size-frequency structure of $P$. astreoides on contemporary reefs, in order to assess the relative importance of juvenile (i.e. small) versus old (i.e. large) colonies to coral cover and population dynamics (sensu Bak \& Meesters 1999); (3) compare the contribution of $P$. astreoides to coral cover on contemporary reefs versus those that were surveyed 10 to $30 \mathrm{yr}$ ago, in order to test whether this species has increased in relative abundance.

\section{MATERIALS AND METHODS}

Contemporary populations of Porites astreoides (Lamarck, 1816) were characterized using surveys of coral reefs in shallow water throughout the Caribbean (Fig. 1). These surveys were designed to elucidate the relationships among the echinoid Diadema antillarum, juvenile corals and macroalgae (Carpenter \& Edmunds 2006), and they provided a photographic dataset for quantifying $P$. astreoides populations. The surveys were completed within a 12 mo period in 2003/2004 by P. J. Edmunds and R. C. Carpenter using a standardized protocol. To place the contemporary population structure of $P$. astreoides in an historic context, the results were compared to data from publications describing similar Caribbean reef habitats between 1974 and 1992. The number of suitable studies was limited, because most did not treat $P$. astreoides separately from other scleractinians, whereas we required publications having data on percentage cover of this species on reefs located close to the 2003/2004 study sites.

Contemporary surveys. The empirical data consisted of photoquadrats recorded during surveys of shallow reefs (5 to $6 \mathrm{~m}$ depth) in Belize, Jamaica,

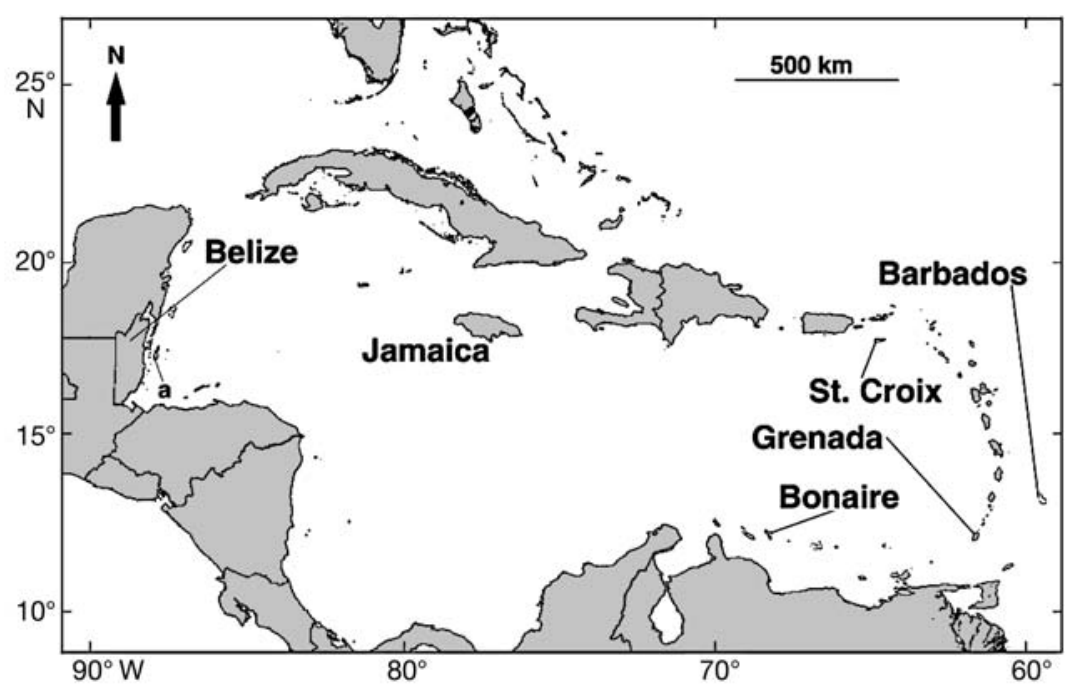

Fig. 1. The 6 study locations in the Caribbean region 
St. Croix, Bonaire, Grenada and Barbados (hereafter: 'locations'; Appendix 1). One or 2 study sites were analyzed per location; regional comparison of the population structure of Porites astreoides was accomplished by pooling sites within location where appropriate. Restriction of the sampling effort to shallow fringing or outer reef communities allowed for regional comparison without a confounding effect of habitat. The ecological features of the locations are described in Carpenter \& Edmunds (2006); P. astreoides was known to occur at the study sites, e.g. in Jamaica (Goreau 1959) and Belize (Littler et al. 1989).

As part of the original study, the benthic community was sampled using both in situ censusing of quadrats $(0.5 \times 0.5 \mathrm{~m})$ sub-divided into 25 squares of equal size $(10 \times 10 \mathrm{~cm})$, as well as photoquadrats $(0.5 \times 0.5 \mathrm{~m})$. For the in situ surveys, the dominant benthic taxanotably scleractinian corals - were scored in each of the 25 squares of the quadrats (providing a $4 \%$ resolution by taxon) using 20 quadrats per site. To quantify the abundance of Porites astreoides, the photoquadrats were analyzed for the presence of the yellow morphotype of this species, which is the most common form in shallow water (Gleason 1993, 1998). The photoquadrats at each site were located at random points along a $40 \mathrm{~m}$ transect positioned haphazardly along the 5 to $6 \mathrm{~m}$ depth contour. This transect was parallel to, and $<3 \mathrm{~m}$ from, the transect used for in situ analysis of benthic community structure, and both transects sampled a single homogeneous area of reef.

Between 19 and 21 photoquadrats per transect were recorded with a digital camera (resolution: 3.34 megapixels) resolving objects as small as $1 \mathrm{~cm}$. Colonies of Porites astreoides were assessed based on the criterion that each colony represents a single area of contiguous coral tissue (Connell 1973). The number and sizes (i.e. planar area) of colonies of $P$. astreoides in each photoquadrat were determined using NIH Image (version 1.62) software, and the results were used to assess the percentage cover (from the area occupied by $P$. astreoides in each quadrat), population density (colonies per quadrat), and size-frequency distribution of colonies (based on colony area and size classes of $50 \mathrm{~cm}^{2}$ ); colonies were quantified if $\geq 50 \%$ of their area was within a photoquadrat, but the size-frequency analyses were completed using colonies that were entirely within a photoquadrat, to avoid under-estimating their size. Percentage cover of $P$. astreoides was expressed relative to the overall cover of scleractinian corals, as estimated from the in situ surveys based on the sub-divided quadrats.

Historical surveys. The analyses of contemporary reefs were compared with data in peer-reviewed publications (Appendix 1), selected using 3 criteria: the studies had to (1) be completed in the 3 decades pre- ceding the present analysis; (2) provide quantitative analyses of coral reefs based on habitats, depth ranges and locations, similar to those sampled in the present study; and (3) contain data on overall percentage cover of scleractinians, as well as separately for Porites astreoides. Because most studies did not distinguish between the morphotypes of $P$. astreoides (sensu Gleason 1993, 1998), their pooled analyses for this species (i.e. for both the yellow and brown morphotypes) provided a conservative test of the hypothesis that the yellow morphotype of $P$. astreoides has increased in abundance. This final criterion-listing of $P$. astreoides cover-proved difficult to meet, and only 11 studies completed between 1974 and 1992, surveying a total of 13 reefs at 6 locations proved adequate for our purpose. Thus, the historic data included here is not an inclusive summary of studies addressing coral community structure in the study locations, or an indication of the data available overall. Studies meeting our selection criteria were used to test the hypothesis that contemporary Caribbean reefs in shallow water differ from those observed over the last 3 decades in terms of both absolute and relative percentage cover of $P$. astreoides.

Statistical analyses. Statistical analyses were completed to determine the extent of regional variation in the contribution of Porites astreoides to contemporary reefs, and the extent to which the contribution of this species to overall coral community structure has changed on a decadal scale. To test for geographic variation in population structure of $P$. astreoides, the percentage cover and colony density were compared among sampled locations using quadrats as replicates. Percentage cover data were arcsine transformed to achieve homoscedasticity, and among-locations comparisons were accomplished using ANOVA. A similar procedure was used for the percentage cover of all scleractinians, and in both cases Bonferroni post-hoc analyses were conducted. The sizes of the P. astreoides colonies were log-transformed to achieve homoscedasticity, and compared among locations using an ANOVA followed by Bonferroni post-hoc comparisons.

To test for temporal variation in the contribution of Porites astreoides to Caribbean reefs, the results from contemporary reefs were pooled using the 6 locations as replicates in order to characterize coral community structure on a regional scale for the current decade. The historic data were grouped by decade in which the field surveys were completed (1970s, 1980s and 1990s), and locations within decade were used as replicates. In all cases, the historic locations were defined broadly by country or island; where $>1$ survey per decade was found meeting our selection criteria, the results were averaged by survey to create a single value for each location per decade. Two series of statistical tests were applied to the historic and the contemporary data, 
using as dependent variable (1) absolute percentage cover of $P$. astreoides, and (2) percentage cover of $P$. astreoides relative to all scleractinians. The contribution of $P$. astreoides to coral community structure was compared among decades using a Kruskal-Wallis test, and a Spearman correlation was used to test for an association between relative percentage cover of $P$. astreoides and time (i.e. decade). Where a significant relationship was detected, Model II regression techniques (Reduced Major Axis, RMA; Sokal \& Rohlf 1995) were used to obtain the best-fit linear relationship, the slope of which was used as an estimate of the rate of change in relative cover of $P$. astreoides $\left(\%\right.$ cover $\left.\mathrm{yr}^{-1}\right)$.

\section{RESULTS}

\section{Contemporary surveys}

Overall coral cover ranged from 4 to $42 \%$, and differed significantly among locations $\left(F_{5,134}=21.69, \mathrm{p}<\right.$ 0.01) with the highest cover in Grenada, and the lowest in Belize. In all 6 locations, colonies of Porites astreoides were conspicuous components of the coral fauna, and in Belize, colonies of $P$. astreoides appeared qualitatively to be the principal species responsible for coral cover.

The mean absolute percentage cover of the yellow morphotype of Porites astreoides ranged from $1.3 \%$ in Bonaire to $11.1 \%$ in Grenada (Fig. 2). Overall, the absolute percentage cover of $P$. astreoides differed significantly among locations $\left(F_{5,136}=3.10, \mathrm{p}=0.01\right)$; however, post-hoc analysis revealed significant differences only between Grenada and Bonaire ( $p=0.02$ ) (Fig. 2). The cover of $P$. astreoides was established with population densities ranging from $0.76 \pm 0.21$ colonies per $0.25 \mathrm{~m}^{2}$ in Belize to $3.00 \pm 0.57$ colonies per $0.25 \mathrm{~m}^{2}$ in Grenada $( \pm \mathrm{SE})$. While the population densities differed significantly among locations $\left(F_{5,136}=2.85, \mathrm{p}=\right.$ 0.02), post-hoc analyses revealed no differences between pairs of locations ( $p>0.05)$. Although the mean absolute percentage cover of $P$. astreoides was low at all locations, the relative percentage cover of this species was high, ranging from $16 \%$ of all scleractinians in Bonaire to $72 \%$ in Belize (see Fig. 4). Overall, on contemporary reefs in shallow water, $P$. astreoides covered $5.1 \pm 0.3 \%$ of the benthos, its colonies occurred at a density of $1.76 \pm 0.34$ colonies per $0.25 \mathrm{~m}^{2}$, and represented $39 \pm 8 \%$ of the total coral cover (mean $\pm \mathrm{SE} ; \mathrm{n}=6$ locations).

At all locations, the cover of Porites astreoides was composed mostly of small colonies $\left(<50 \mathrm{~cm}^{2}\right.$ in area), and size-frequency distributions were skewed ( $\mathrm{n}=16$ to 103 colonies per location) (Table 1, Fig. 3). The

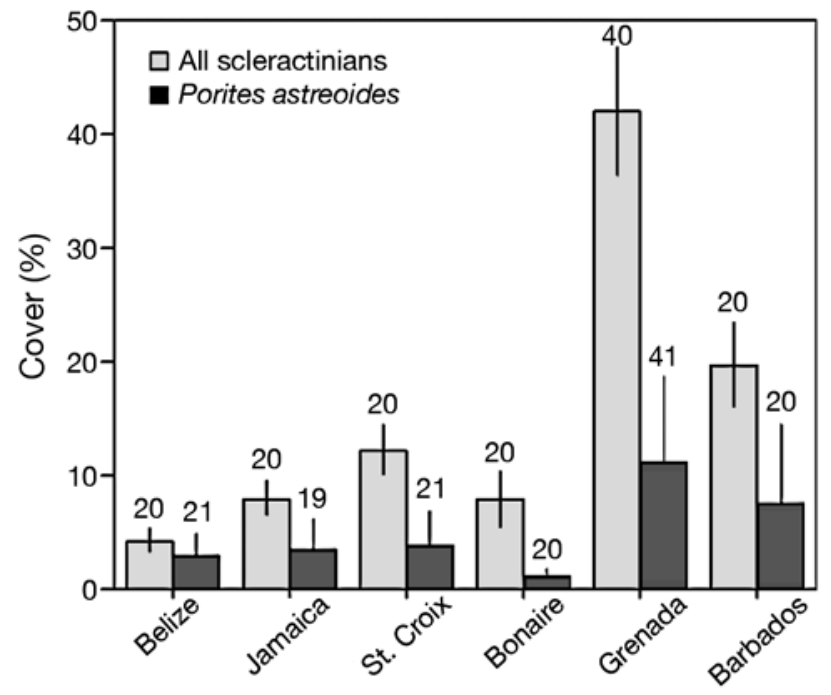

Fig. 2. Percentage cover of Porites astreoides and of all scleractinians at the 6 study locations. Surveys were conducted at 1 site per location, except at Grenada, where 2 sites were studied. Data are mean and SE, sample sizes shown above bars; error bars are asymmetrical due to arcsine transformation of the data

upper tails of these distributions were marked by colonies as large as $1000 \mathrm{~cm}^{2}$ (in Grenada), but most large colonies were in the 250 to $500 \mathrm{~cm}^{2}$ size class. The logarithms of colony size-frequency distributions were normally distributed (after Underwood 1997, Bak \& Meesters 1999), and mean colony sizes differed significantly among sites $\left(F_{5,249}=3.59, \mathrm{p}=\right.$ 0.04). Post-hoc analyses revealed that colonies differed in size between Bonaire and Grenada ( $p$ < $0.05)$, but not between any other pairs of locations $(\mathrm{p}>0.05)$.

\section{Historical surveys}

The 11 peer-reviewed studies analyzed here (see Fig. 4) described surveys conducted between 1974 and 1992 on reefs in Barbados, Grenada, Jamaica, and the US Virgin Islands; historical data meeting the selection criteria could not be located for Belize and Bonaire. Overall, the historic data reveal that between 1974 and 1992 shallow coral reefs (<10 m depth) in the Caribbean were characterized by $26.0 \pm 2.7 \%$ (mean \pm SE) total coral cover, of which $12.3 \pm 1.7 \%$ was Porites astreoides (which covered $4.2 \pm 0.4 \%$ of the reefs) (Fig. 4). Overall coral cover declined from $50 \%$ ( $\mathrm{n}=7$ surveys) in the 1970 s to $15 \%$ ( $\mathrm{n}=1$ survey) in the $1990 \mathrm{~s}$, but the absolute cover of $P$. astreoides remained similar at $4.4 \%$ ( $\mathrm{n}=7$ surveys) in the $1970 \mathrm{~s}$ and $4.0 \%$ ( $\mathrm{n}=1$ survey) in the 1990s. Importantly, the relative 
Table 1. Porites astreoides. Size-frequency distribution (no. of colonies) at the 6 locations in this study (from photoquadrats in Carpenter \& Edmunds 2006)

\begin{tabular}{|c|c|c|c|c|c|c|c|c|c|c|c|c|}
\hline \multirow[t]{2}{*}{ Location } & \multirow[b]{2}{*}{$0-50$} & \multirow[b]{2}{*}{$51-100$} & \multirow[b]{2}{*}{$101-150$} & \multirow[b]{2}{*}{$151-200$} & \multirow[b]{2}{*}{$201-250$} & \multicolumn{2}{|c|}{ - Size class $\left(\mathrm{cm}^{2}\right)-$} & \multirow[b]{2}{*}{$351-400$} & \multirow[b]{2}{*}{$401-450$} & \multirow[b]{2}{*}{$451-500$} & \multirow[b]{2}{*}{$501-2500$} & \multirow[t]{2}{*}{ Total } \\
\hline & & & & & & $251-300$ & $301-350$ & & & & & \\
\hline Barbados & 32 & 8 & 2 & 0 & 3 & 0 & 2 & 0 & 1 & 0 & 1 & 49 \\
\hline Belize & 10 & 3 & 0 & 0 & 1 & 0 & 1 & 0 & 0 & 1 & 0 & 16 \\
\hline Bonaire & 16 & 5 & 0 & 0 & 0 & 0 & 0 & 0 & 0 & 0 & 0 & 21 \\
\hline Grenada & 52 & 23 & 7 & 7 & 3 & 3 & 3 & 0 & 1 & 0 & 4 & 103 \\
\hline Jamaica & 22 & 2 & 2 & 1 & 0 & 0 & 2 & 0 & 0 & 0 & 0 & 29 \\
\hline St. Croix & 27 & 6 & 0 & 0 & 2 & 1 & 0 & 0 & 1 & 0 & 0 & 37 \\
\hline
\end{tabular}

contribution of $P$. astreoides to coral cover increased from $9 \%$ ( $\mathrm{n}=10$ surveys) in the 1970 s to $27 \%$ ( $\mathrm{n}=$ 1 survey) in the 1990s (Fig. 4). Together with the analyses for the current decade, these data describe significant differences among 4 decades for overall coral cover $\left(F_{3,14}=4.02, \mathrm{p}=0.03\right)$, as well as for relative cover $\left(F_{3,23}=10.64, \mathrm{p}<0.01\right)$ of $P$. astreoides. The absolute cover of $P$. astreoides did not vary among decades $\left(F_{3,20}=0.32, \mathrm{p}=0.81\right)$ (Fig. 5). The changes in relative cover of $P$. astreoides were significantly and positively associated with time $(\mathrm{r}=0.763, \mathrm{df}=27, \mathrm{p}<$ 0.01 ), and the RMA slope of the relationship indicated that this species has increased in relative cover at a rate of $1.52 \% \mathrm{yr}^{-1}$ since the $1970 \mathrm{~s}$ (Fig. 5).

\section{DISCUSSION}

The decline of coral cover on Caribbean reefs has been underway since at least the early 1980s (Aronson et al. 2005), and arguably it may have begun centuries ago (Jackson 1997). Recent studies have, however, brought a greater appreciation of the severity of the coral losses that have taken place (Knowlton 2001, Gardner et al. 2003, Bellwood et al. 2004). Research has focused on taxa that are declining rapidly in abundance, which are often the dominant scleractinians responsible for reef construction (Aronson \& Precht 2001). While coral reefs may eventually be replaced by macroalgae and slime (Pandolfi et al. 2005), many reefs
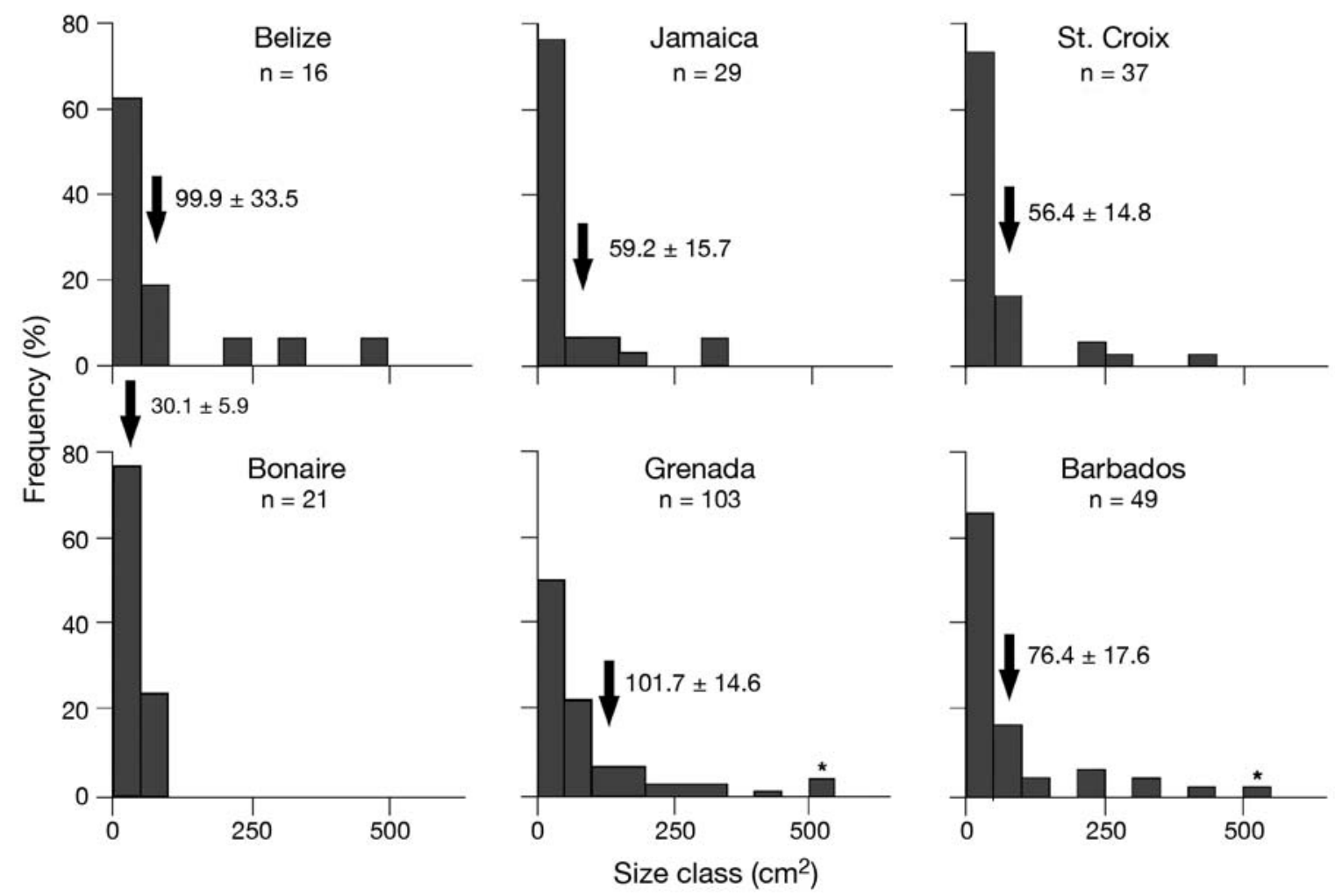

Fig. 3. Porites astreoides. Size-frequency distributions $\left(50 \mathrm{~cm}^{2}\right.$ intervals $)$ of colonies at each location. Size classes range from $1 \mathrm{~cm}^{2}$ (smallest detectable size) to $>1000 \mathrm{~cm}^{2}$; colonies $>500 \mathrm{~cm}$ are pooled into a single size class $(*)$. Arrows: mean colony size $(\text { mean } \pm \text { SE given next to arrow) })_{i}$ : sample size 


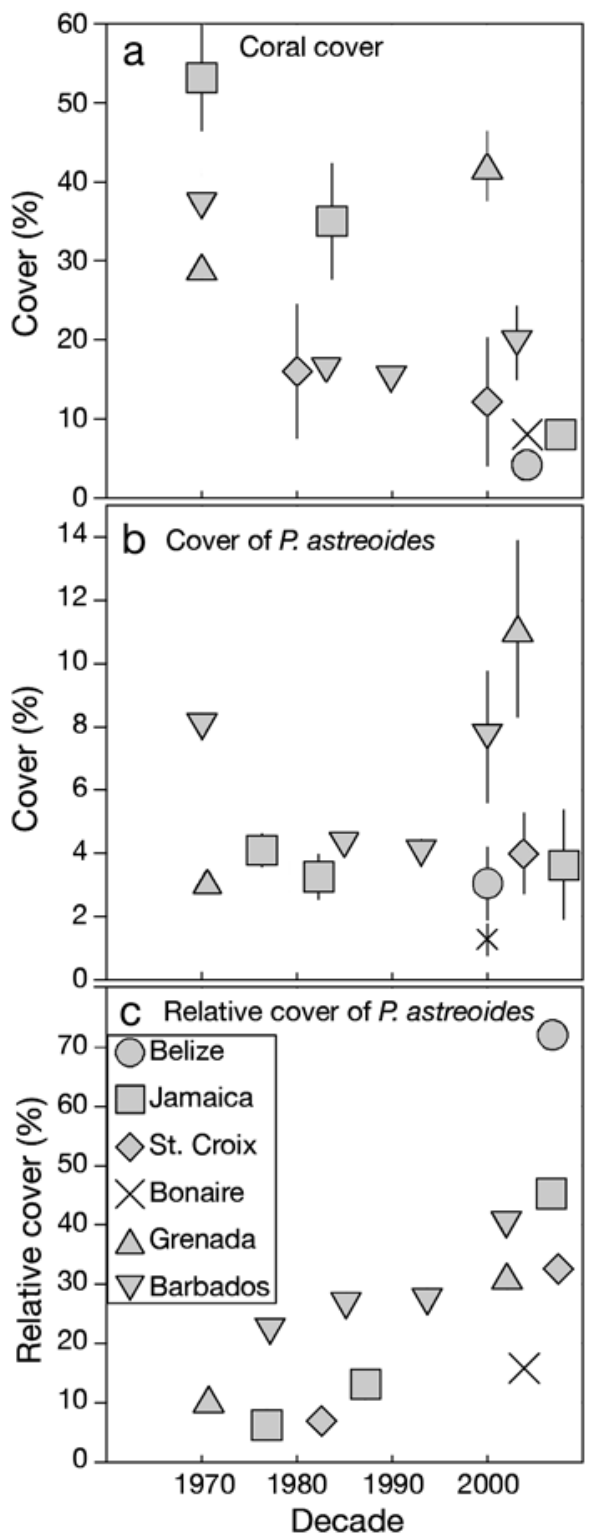

Fig. 4. Coral cover at 6 locations surveyed since 1974; abscissas are categorical by decade, and within each panel data are offset as needed within each decade for clarity. (a) Overall cover of all scleractinian corals, (b) cover of Porites astreoides, and (c) relative contribution of $P$. astreoides to overall coral cover. Values in (a) and (b) are mean \pm SE of cover for each decade; values in (c) are the relative percentage of the total coral cover that is composed of $P$. astreoides. Symbols for historical data are based on 1 to 5 studies (Appendix 1); post2000 data from the present study

may endure in an altered state dominated by scleractinians having life-history characteristics that make them resistant to environmental degradation (Knowlton 2001, Precht \& Miller 2006). Such reefs would differ from those of the recent past, missing for example, massive and topographically complex reef-building corals such as Acropora and Montastraea in the
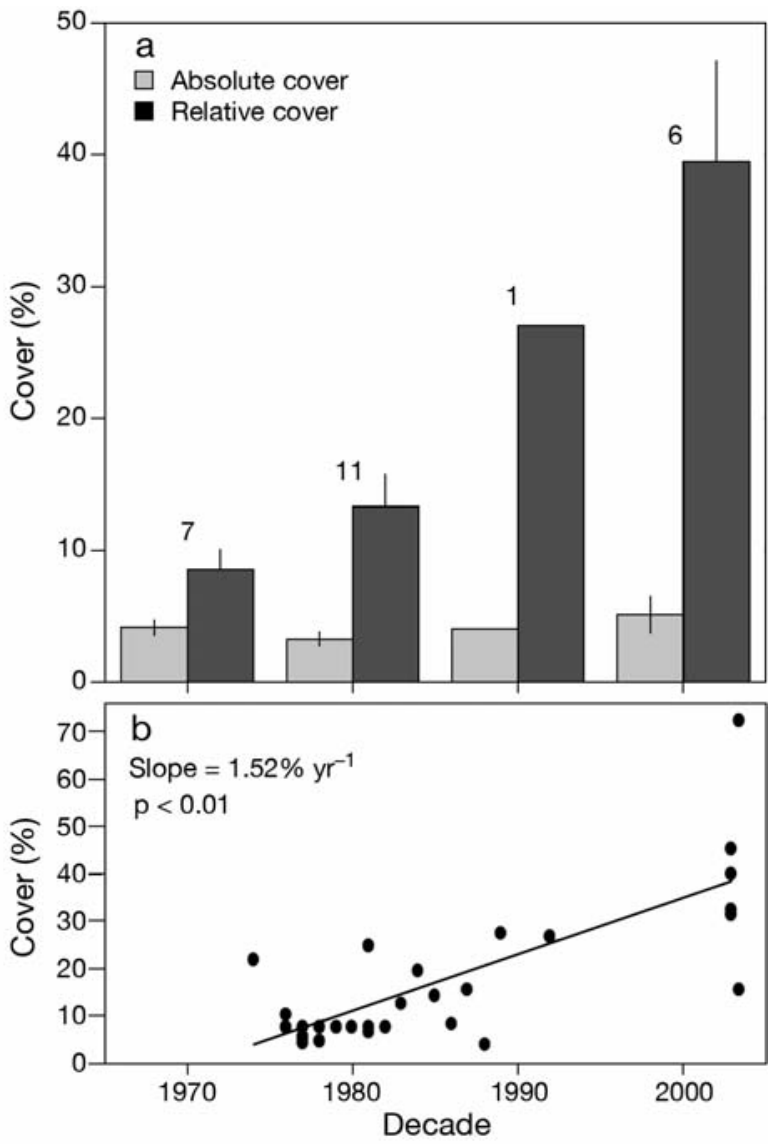

Fig. 5. Porites astreoides. Percentage cover throughout the Caribbean. (a) Absolute cover of $P$. astreoides, and percentage of all scleractinian corals. Values are mean and SE, sample sizes shown above bars. (b) Mean cover of $P$. astreoides relative to all scleractinians, by year in which the study was completed. Linear regression fitted by Model II, RMA technique

(Sokal \& Rohlf 1995). Data sources given in Appendix 1

Caribbean (Goreau 1959, Precht \& Miller 2006), and Porites and Acropora in the Pacific (Done 1987, van Woesik \& Done 1997). In their place might be species that form small colonies, settle in large numbers, grow rapidly, and are short lived, i.e. weedy species (Knowlton 2001, Precht \& Miller 2006).

Our results show that Porites astreoides is now one of the most abundant corals on shallow reefs throughout the Caribbean, and they support the hypothesis that this species has increased in relative abundance over the last 30 yr. The increase in relative cover has been driven mostly by declining cover of other scleractinians, although our surveys in Grenada and Barbados suggest that increases in absolute cover of $P$. astreoides have also taken place. P. astreoides may thus become a dominant coral on Caribbean reefs in shallow water.

Our study, among others (e.g. Gardner et al. 2003), demonstrates that coral cover is low $(<15 \%)$ in shallow water Caribbean reefs, and that Porites astreoides 
now is a dominant component of coral communities. The historical data show a striking loss of overall coral cover and its replacement by macroalgae in both the Caribbean (Gardner et al. 2003) and the tropical Pacific (McCook 1999), with this transition being driven by a variety of disturbances (Knowlton 2001, Bellwood et al. 2004). In a growing number of cases, the coral community has been monitored long enough following the disturbance(s), such that shifts already have been detected in coral species composition (Loya et al. 2001) and the relative abundance of differing lifehistory strategies (Aronson et al. 2004). To date, most of these examples have come from specific reefs or a single location.

Examples of recent changes in coral species composition come from the replacement of Acropora cervicornis by Agaricia tenuifolia in Belize (Aronson \& Precht 1997), and by Porites porites in the Bahamas (Curran et al. 1994), as well as the replacement of $P$. furcata by A. tenuifolia in northwestern Panama (Aronson et al. 2004). The geographically widespread bleaching episodes of the 1980s and 1990s also have caused changes in coral species assemblages. For example, the globally widespread bleaching events of 1998 caused high mortality among fast growing branching corals in Okinawa (Loya et al. 2001), increases in the relative abundance of massive Porites and Favia species in Kenya (McClanahan \& Maina 2003), and almost 'total mortality' of Agaricia tenuifolia on lagoon reefs in Belize (Aronson et al. 2000). More subtle effects on coral assemblages have also been recorded, such as low levels of chronic mortality and lack of recruitment, which caused shifts in the generic abundance of juvenile corals in St. John between 1994 and 2001 (Edmunds 2004), and declines in cover for all coral species except agaracids in deep water (30 to $40 \mathrm{~m}$ ) off Curaçao and Bonaire between 1973 and 2002 (Bak et al. 2005). There are also a few reports of changes in coral species assemblages through range extensions, such as for Acropora along the Atlantic coast of Florida (Precht \& Aronson 2004), as well as by invasion in the case of Tubastrea in the Caribbean (Fenner \& Banks 2004). Although changing species assemblages through local extinctions have yet to be reported for scleractinians in recent times, such events exist in the fossil record (Edinger \& Risk 1995, Pandolfi et al. 2002), and are thought to have occurred for several hydrocorals in the Galapagos Islands in the 1980s (Glynn \& deWeerdt 1991, Glynn \& Feingold 1992). Changes in coral species assemblages have occurred in recent times, but to our knowledge, the present study is the first to report a region-wide increase in relative cover of one resilient scleractinian.

A striking feature of the contemporary populations of Porites astreoides is the high abundance of juvenile colonies, which is a common feature of scleractinian populations that reflects the effects of strong recruitment (Bak \& Meesters 1999). Small colonies can also be created by fission (Hughes \& Jackson 1980), but it is unlikely that many of the small colonies of $P$. astreoides originated by this mechanism, as few showed signs of the antecedent skeletal framework that is created when a large colony splits by partial mortality into smaller pieces (Hughes \& Jackson 1980). It is difficult to determine whether historic populations of $P$. astreoides were influenced as strongly by small colonies as extant populations, largely because size-frequency distributions for this species have rarely been reported. In contrast, such information is preserved in the fossil record (Scoffin 1992), and while this record may differentially preserve calcareous organisms based on size (Cummins et al. 1986), and complicate the elucidation of demographic traits through time-averaging (Pandolfi 2002), it offers a promising means to explore temporal variability in the population structure of reef corals such as $P$. astreoides.

On a shorter time scale, evidence for the temporal stability of the population structure of Porites astreoides can be found in 2 types of studies: (1) direct and indirect studies of coral recruitment on Caribbean reefs, in which this species has been recorded as one of the most abundant juvenile corals since at least 1975 (Bak \& Engel 1979, Rogers et al. 1984), and forms populations that recover quickly from disturbances (Lirman \& Miller 2003); (2) older studies of coral populations, among which one study from the late 1970 s (Hughes \& Jackson 1985) - albeit for a reef at $35 \mathrm{~m}$ depth where the brown morph of $P$. astreoides probably dominated (Gleason 1993) — recorded a size-frequency distribution for this species that is similar to those reported here. A similar size-frequency distribution was also reported in the early 1990s for the shallow reef off Buck Island (St. Croix, US Virgin Islands) (Bythell et al. 1993) where the yellow morph of $P$. astreoides is common (P. J. Edmunds pers. obs. in 2004). In the early 1970s, Kissling (1977) used growth bands in sectioned colonies of $P$. astreoides from a reef flat in the Florida Keys to reveal a population age structure similar to that inferred here from the population size structure. Although the population structure reported by Kissling (1977) showed that colonies in the 1 to 3 yr age group were poorly represented, this was probably an artifact of ageing colonies by sectioning, which would have been difficult for the smallest colonies. Together with the present results, these findings suggest that strong recruitment and positive skewing of the population structure is characteristic of $P$. astreoides, and reflects the capacity for population growth through further recruitment. While population increases could also occur through the growth of exist- 
ing colonies, this mechanism may be less important, given the rarity of large colonies of $P$. astreoides, even though their mortality rates are low (Hughes \& Jackson 1980, P. J. Edmunds unpubl.).

This study shows that Porites astreoides has been successful in an era that portends a gloomy future for scleractinian corals (Knowlton 2001), yet it is unclear at a mechanistic level why populations of this species are thriving while others corals are dying. Adult $P$. astreoides are quite resistant to adverse conditions, e.g. high sedimentation rates (Tomascik \& Sanders 1987, Gleason 1998) and elevated temperature (Gates 1990), and they typically contain Symbiodinium taxa (Clades A4a, A3, B1) that are hardy with respect to bleaching (LaJeunesse 2002). Therefore, the recent success of this species may be driven both by the production of adult colonies that are resilient to environmental stress, and by a weedy life-history strategy (notably to support a high rate of recruitment). In addition to the classic benefits of the latter (Knowlton 2001), the capacity for self-fertilization (Brazeau et al. 1998) presumably is an additional advantage for $P$. astreoides at low population densities, and might serve to reduce the consequences of an Allee effect (Courchamp et al. 1999).

Acknowledgements. This analysis was made possible by an award to D.H.G. from the Research Experience for Undergraduates program of the US National Science Foundation (supplement to Grant DEB 0343570 to P.J.E.), and is based on data collected with the support of the National Geographic Society (Grant No. 7371-02 to P.J.E. and R.C.C.). Additional support for this project was obtained from the Sea Grant Program of the University of Puerto Rico (\#R-101-2-02 to P.J.E.). We thank 3 anonymous reviewers for comments that improved an earlier draft of this paper. This is contribution number 148 of the Marine Biology Program at California State University, Northridge.

\section{LITERATURE CITED}

Aronson RB, Precht WF (1997) Stasis, biological disturbance, and community structure of a Holocene coral reef. Paleobiology 23:326-346

Aronson RB, Precht WF (2001) Evolutionary paleoecology of Caribbean coral reefs. In: Allmon WD, Bottjer DJ (eds) Evolutionary paleoecology: the ecological context of macroevolutionary change. Columbia University Press, New York, p 171-233

Aronson RB, Precht WF, Macintyre IG, Murdoch TJT (2000) Coral bleach-out in Belize. Nature 405:36

Aronson RB, Macintyre IG, Wapnick CM, O'Neill MW (2004) Phase shifts, alternative states and the unprecedented convergence of two reef systems. Ecology 85:1876-1891

Aronson RB, Macintyre IG, Lewis SA, Hilbun NL (2005) Emergent zonation and geographic convergence of coral reefs. Ecology 86:2586-2600

Bak RPM, Engel MS (1979) Distribution, abundance and survival of juvenile hermatypic corals (Scleractinia) and the importance of life history strategies in the parent commu- nity. Mar Biol 54:341-352

Bak RPM, Meesters EH (1999) Population structure as a response of coral communities to global change. Am Zool 39:56-65

Bak RPM, Nieuwland G, Meesters EH (2005) Coral reef crisis in deep and shallow reefs: 30 years of constancy and change in reefs of Curacao and Bonaire. Coral Reefs 24: $475-479$

> Bellwood DR, Hughes TP, Folke C, Nystrom M (2004) Confronting the coral reef crisis. Nature 429:827-833

> Brazeau DA, Gleason DF, Morgan ME (1998) Self-fertilization in brooding hermaphroditic Caribbean corals: evidence from molecular markers. J Exp Mar Biol Ecol 231:225-238

> Bythell JC, Gladfelter EH, Bythell M (1993) Chronic and catastrophic natural mortality of three common Caribbean reef corals. Coral Reefs 12:143-152

Carpenter RC, Edmunds PJ (2006) Local and regional scale recovery of Diadema promotes recruitment of scleractinian corals. Ecol Lett 9:271-280

$>$ Chornesky EA, Peters EC (1987) Sexual reproduction and colony growth in the scleractinian coral Porites astreoides. Biol Bull 172:161-177

Connell JH (1973) Population ecology of reef-building corals. In: Jones OA, Endean R (eds) Biology and geology of coral reefs, Vol 2. Academic Press, New York, p 205-245

Courchamp F, Clutton-Brock T, Grenfell B (1999) Inverse density dependence and the Allee effect. Trends Ecol Evol 14:405-410

Cummins H, Powell EN, Stanton RJ, Staff G (1986) The size-frequency distribution in palaeoecology: effects of taphonomic process during formation of molluscan death assemblages in Texas Bays. Palaeontology 29:495-518

Curran HA, Smith DP, Meigs LC, Pufall AE, Greer ML (1994) The health and short-term change of two coral patch reefs, Fernandez Bay, San Salvador Island, Bahamas. In: Ginsburg RN (ed) Proc Colloquium on Global Aspects of Coral Reefs: Health, Hazards, and History, 1993, Rosenstiel School of Marine and Atmospheric Science, University of Miami, FL, p 147-153

- Done TJ (1987) Simulation of the effects of Acanthaster planci on the population structure of massive corals in the genus Porites: evidence of population resilience? Coral Reefs 6: 75-90

Edinger EN, Risk MJ (1995) Preferential survivorship of brooding corals in a regional extinction. Paleobiology 21: $200-219$

> Edmunds PJ (2004) Juvenile coral population dynamics track rising seawater temperature on a Caribbean reef. Mar Ecol Prog Ser 269:111-119

$>$ Edmunds PJ, Bruno JF (1996) The importance of sampling scale in ecology: kilometer-wide variation in coral reef communities. Mar Ecol Prog Ser 143:165-171

Edmunds PJ, Roberts DA, Singer R (1990) Reefs of the northeastern Caribbean. I. Scleractinian populations. Bull Mar Sci 1990:780-789

Fenner D, Banks K (2004) Orange cup coral Tubastrea coccinea invades Florida and the Flower Garden Banks, northwestern Gulf of Mexico. Coral Reefs 23:505-507

Gardner TA, Cote IM, Gill JA, Grant A, Watkins AR (2003) Long-term, region-wide declines in Caribbean corals. Science 301:958-960

- Gates RD (1990) Seawater temperature and sublethal coral bleaching in Jamaica. Coral Reefs 8:193-197

Gleason DF (1993) Differential effects of ultraviolet radiation on green and brown morphs of the Caribbean coral Porites astreoides. Limnol Oceanogr 38:1452-1463

Gleason DF (1998) Sedimentation and distribution of green 
and brown morphs of the Caribbean coral Porites astreoides Lamarck. J Exp Mar Biol Ecol 230:73-89

Glynn PW, deWeerdt WH (1991) Elimination of two reefbuilding hydrocorals following the 1982-1983 El Niño warming event. Science 253:69-71

Glynn PW, Feingold JS (1992) Hydrocoral species not extinct. Science 257:1845

Goodwin MH, Cole MJC, Stewart WE, Zimmerman BL (1976) Species density and associations in Caribbean reef corals. J Exp Mar Biol Ecol 24:19-31

Goreau TF (1959) The ecology of Jamaican reefs. I. Species composition and zonation. Ecology 40:67-90

Hoegh-Guldberg O (1999) Climate change, coral bleaching and the future of the world's coral reefs. Mar Freshw Res 50:839-866

Hughes TP (1989) Community structure and diversity of coral reefs: the role of history. Ecology 70: 275-279

Hughes TP, Jackson JBC (1980) Do corals lie about their age? Some demographic consequences of partial mortality, fission, and fusion. Science 209:713-715

Hughes TP, Jackson JBC (1985) Population dynamics and life histories of foliaceous corals. Ecol Monogr 55:141-166

Hughes TP, Baird AH, Bellwood DR, Card M and others (2003) Climate change, human impacts, and the resilience of coral reefs. Science 301:929-933

Huston M (1985) Patterns of species diversity in relation to depth at Discovery Bay, Jamaica. Bull Mar Sci 37:928-935

Idjadi JA, Lee SC, Bruno JF, Precht WF, Allen-Requa L, Edmunds PJ (2006) Rapid phase-shift reversal on a Jamaican coral reef. Coral Reefs 25:209-211

Jackson JBC (1997) Reefs since Columbus. Coral Reefs 16: S23-S32

Kissling DL (1977) Population structure characteristics for some Paleozoic and modern colonial corals. In: Chevalier JP, Debrenne F, Beauvais L, Semenoff Tian-Chansky P and others (eds) 2nd Int Symp Corals Fossil Coral Reefs, Paris, September 1975, p 497-506

Knowlton N (2001) The future of coral reefs. Proc Natl Acad Sci USA 98:5419-5425

LaJeunesse T (2002) Diversity and community structure of symbiotic dinoflagellates from Caribbean coral reefs. Mar Biol 141:387-400

Liddell WD, Olhorst SL (1987) Patterns of reef community structure, North Jamaica. Bull Mar Sci 40:311-329

> Lirman D, Miller MW (2003) Modeling and monitoring tools to assess recovery status and convergence rates between restored and undisturbed coral reef habitats. Restor Ecol 11:448-456

Littler MM, Tayler PR, Littler DS (1989) Complex interactions in the control of coral zonation on a Caribbean reef flat. Oecologia 80:331-340

Loya Y, Sakai K, Yamazato K, Nakano Y, Sambali H, van Woesik R (2001) Coral bleaching: the winners and losers. Ecol Lett 4:122-131

McClanahan TR, Maina J (2003) Response of coral assem- blages to the interaction between natural temperature variation and rare warm-water events. Ecosystems 6: $551-563$

McCook LJ (1999) Macroalgae, nutrients and phase shifts on coral reefs: scientific issues and management consequences for the Great Barrier Reef. Coral Reefs 18:357-367

> McGuire MP (1998) Timing of larval release by Porites astreoides in the northern Florida Keys. Coral Reefs 17: 369-375

Mumby PJ, Harborne AR, Williams J, Kappel CV and others (2007) Trophic cascade facilitates coral recruitment in a marine reserve. Proc Natl Acad Sci USA 104: 8362-8367

Pandolfi JM (2002) Coral community dynamics at multiple scales. Coral Reefs 21:13-23

Pandolfi JM, Jackson JBC (2006) Ecological persistence interrupted in Caribbean coral reefs. Ecol Lett 9:818-826

Pandolfi JM, Lovelock CE, Budd AF (2002) Character release following extinction in a Caribbean reef coral species complex. Evolution 56:479-503

Pandolfi JM, Jackson JBC, Baron N, Bradbury RH and others (2005) Are U.S. coral reefs on the slippery slope to slime? Science 307:1725-1726

Precht WF, Aronson RB (2004) Climate flickers and range shifts of reef corals. Front Ecol Environ 2:307-314

Precht WF, Miller SL (2006) Ecological shifts along the Florida reef tract: the past as a key to the future. In: Aronson RB (ed) Geological approaches to coral reef ecology. Springer, New York, p 237-312

> Rogers CS, Fitz HC, Gilnack M, Beets J, Hardin J (1984) Scleractinian coral recruitment patterns at Salt River Submarine Canyon, St. Croix, US Virgin Islands. Coral Reefs 3:69-76

Rylaarsdam KW (1983) Life histories and abundance patterns of colonial corals on Jamaican reefs. Mar Ecol Prog Ser 13: 249-260

> Scoffin TP (1992) Taphonomy of coral reefs: a review. Coral Reefs 11:57-77

- Scoffin TP (1993) The geological effects of hurricanes on coral reefs and the interpretation of storm deposits. Coral Reefs 12:203-221

Sokal RR, Rohlf FJ (1995) Biometry. Freeman, New York

Soong K (1991) Sexual reproduction patterns of shallowwater reef corals in Panama. Bull Mar Sci 49:832-846

- Tomascik T, Sanders F (1987) Effects of eutrophication on reef-building corals II. Structure of scleractinian coral communities on fringing reefs, Barbados, West Indies. Mar Biol 94:53-75

Underwood AJ (1997) Experiments in ecology. Cambridge University Press

van Woesik R, Done TJ (1997) Coral communities and reef growth in the southern Great Barrier Reef. Coral Reefs 16:103-115

> Wittenberg M, Hunte W (1992) Effects of eutrophication and sedimentation on juvenile corals. Mar Biol 112:131-138 
Appendix 1. Scleractinian coral community analyses used in the preparation of Figs. $4 \&$ 5. Density: no. of colonies of $P$. astreoides in a $0.25 \mathrm{~m}^{2}$ quadrat. Values are mean \pm variability (no. of quadrats or transects). n/a: not available; C\&E: Carpenter \& Edmunds (2006)

\begin{tabular}{|c|c|c|c|c|c|c|}
\hline Location & Year & $\begin{array}{c}\text { All scleractinia } \\
\text { Total cover } \\
(\%)\end{array}$ & $\begin{array}{l}\text { Absolute cover } \\
(\%)\end{array}$ & $\begin{array}{l}\text { Porites astreoides } \\
\text { Relative cover } \\
\qquad(\%)\end{array}$ & $\begin{array}{c}\text { Density } \\
\text { (colonies quadrat }^{-1} \text { ) }\end{array}$ & Source \\
\hline \multicolumn{7}{|l|}{ Barbados } \\
\hline \multirow[t]{4}{*}{ North Bellairs Reef } & 1974 & $37^{\mathrm{a}}$ & $8^{\mathrm{a}}$ & $22^{\mathrm{b}}$ & $\mathrm{n} / \mathrm{a}$ & Scoffin (1993) \\
\hline & 1981 & $16^{\mathrm{a}}$ & $4^{\mathrm{a}}$ & $25^{\mathrm{b}}$ & $\mathrm{n} / \mathrm{a}$ & Scoffin (1993) \\
\hline & 1992 & $15^{\mathrm{a}}$ & $4^{\mathrm{a}}$ & $27^{\mathrm{a}}$ & $\mathrm{n} / \mathrm{a}$ & Scoffin (1993) \\
\hline & 2003 & $19.6 \pm 3.2(20)$ & $7.7 \pm 2.1(20)$ & $39.2^{\mathrm{b}}$ & $2.5 \pm 0.5(20)$ & $\mathrm{C} \& \mathrm{E}$, this study \\
\hline Kings Beach, Drift Wood & 1989 & $16.4 \pm 10.2(2)^{\mathrm{d}}$ & $4.5^{\mathrm{c}}$ & $27.7 \pm 3.3(4)^{\mathrm{e}}$ & $\mathrm{n} / \mathrm{a}$ & $\begin{array}{l}\text { Wittenberg \& } \\
\text { Hunte (1992) }\end{array}$ \\
\hline \multicolumn{7}{|l|}{ Belize } \\
\hline Turneffe Atoll & 2004 & $4.2 \pm 1.9(20)$ & $3.0 \pm 1.2(21)$ & $72.5^{\mathrm{b}}$ & $0.8 \pm 0.2(21)$ & C\&E, this study \\
\hline \multicolumn{7}{|l|}{ Bonaire } \\
\hline Karpata & 2004 & $8.0 \pm 4.0(20)$ & $1.3 \pm 0.5(20)$ & $15.8^{\mathrm{b}}$ & $1.05 \pm 0.4(20)$ & C\&E, this study \\
\hline \multicolumn{7}{|l|}{ Grenada } \\
\hline Saline Island & 1976 & $29.1^{\mathrm{f}}$ & $3.1 \pm 5.4(3)^{g}$ & $10.6^{\mathrm{b}}$ & $\mathrm{n} / \mathrm{a}$ & Goodwin et al. (1976) \\
\hline Grand Anse Bay & 2003 & $42 \pm 4.5(40)^{\mathrm{h}}$ & $11.1 \pm 2.8(41)^{\mathrm{h}}$ & $26.5^{\mathrm{b}}$ & $3.0 \pm 0.6(41)^{\mathrm{h}}$ & C\&E, this study \\
\hline \multicolumn{7}{|l|}{ Jamaica } \\
\hline \multirow[t]{6}{*}{ Discovery Bay, fore reef } & 1976 & $\mathrm{n} / \mathrm{a}$ & $\mathrm{n} / \mathrm{a}$ & $8 \pm 5(9)^{\mathrm{i}}$ & $\mathrm{n} / \mathrm{a}$ & Rylaarsdam (1983) \\
\hline & 1977 & $\mathrm{n} / \mathrm{a}$ & $\mathrm{n} / \mathrm{a}$ & $6 \pm 8(9)^{\mathrm{i}}$ & $\mathrm{n} / \mathrm{a}$ & Rylaarsdam (1983) \\
\hline & 1977 & $60.0 \pm 6.1(3)^{j}$ & $2.8 \pm 3.1(3)^{\mathrm{j}}$ & $4.7^{\mathrm{b}}$ & $\mathrm{n} / \mathrm{a}$ & Huston (1985) \\
\hline & 1977 & $42.0 \pm 13.1(3)^{\mathrm{j}}$ & $2.4 \pm 1.3(3)^{\mathrm{j}}$ & $5.7^{b}$ & $\mathrm{n} / \mathrm{a}$ & Huston (1985) \\
\hline & 1978 & $\mathrm{n} / \mathrm{a}$ & $\mathrm{n} / \mathrm{a}$ & $5 \pm 4(9)^{\mathrm{i}}$ & $\mathrm{n} / \mathrm{a}$ & Rylaarsdam (1983) \\
\hline & $1977-1982$ & $60^{\mathrm{a}}$ & $4.74^{\mathrm{a}}$ & $7.9^{\mathrm{b}}$ & $\mathrm{n} / \mathrm{a}$ & Liddell \& Olhorst (1987) \\
\hline \multirow[t]{5}{*}{ Rio Bueno } & 1983 & $27.2^{\mathrm{k}}$ & $3.4^{\mathrm{c}}$ & $12.7^{\mathrm{k}}$ & $\mathrm{n} / \mathrm{a}$ & Hughes (1989) \\
\hline & 1984 & $28.8^{\mathrm{k}}$ & $4.1^{\mathrm{c}}$ & $14.3^{\mathrm{k}}$ & $\mathrm{n} / \mathrm{a}$ & Hughes (1989) \\
\hline & 1985 & $20.9^{\mathrm{k}}$ & $3.0^{\mathrm{c}}$ & $14.3^{\mathrm{k}}$ & $\mathrm{n} / \mathrm{a}$ & Hughes (1989) \\
\hline & 1986 & $11.9^{\mathrm{k}}$ & $1.0^{\mathrm{c}}$ & $8.6^{\mathrm{k}}$ & $\mathrm{n} / \mathrm{a}$ & Hughes (1989) \\
\hline & 1987 & $10.4^{\mathrm{k}}$ & $1.6^{\mathrm{c}}$ & $15.8^{\mathrm{k}}$ & $\mathrm{n} / \mathrm{a}$ & Hughes (1989) \\
\hline Port Antonio & 2003 & $8.0 \pm 1.6(20)$ & $3.6 \pm 1.8(19)$ & $45.3^{\mathrm{b}}$ & $1.5 \pm 0.4(19)$ & C\&E, this study \\
\hline \multicolumn{7}{|l|}{ St. Croix } \\
\hline Salt River Canyon & 1981 & $16 \pm 4(2)^{1}$ & $1.1^{\mathrm{c}}$ & $6.9 \pm 0.4(2)^{1}$ & $\mathrm{n} / \mathrm{a}$ & Rogers et al. (1984) \\
\hline St. John & 1988 & $\mathrm{n} / \mathrm{a}$ & $\mathrm{n} / \mathrm{a}$ & $4.9^{\mathrm{m}}$ & $\mathrm{n} / \mathrm{a}$ & Edmunds et al. (1990) \\
\hline Tague Bay, fore reef & 2003 & $12.2 \pm 1.9(20)$ & $4.0 \pm 1.3(21)$ & $32.6^{\mathrm{b}}$ & $1.8 \pm 0.5(21)$ & C\&E, this study \\
\hline
\end{tabular}

Editorial responsibility: Matthias Seaman, Oldendorf/Luhe, Germany
Submitted: May 22, 2007; Accepted: February 19, 2008

Proofs received from author(s): April 11, 2008 